\title{
Catolicismo, Gentilismo e Mestiçagem na África Ocidental e Centro Ocidental no século XVIII
}

\author{
Catholicism, Gentilism and Mestizaje in West Africa and West Center in the \\ eighteenth century
}

Suely Cordeiro Almeida*

\begin{abstract}
Resumo
Este trabalho trata dos processos de mescla cultural que se deram nos enclaves ibéricos da África Ocidental e Centro Ocidental, em especial nas formas de catolicismo mestiço surgidos nessas regiões. Realiza uma discussão sobre as relações desenvolvidas entre os lusos e os autóctones e as formas que encontraram para viver as religiões. O papel do governador ilustrado D. Francisco Inocêncio de Souza Coutinho e suas ações para coibir os gentilismos. Para tanto, foram utilizadas fontes primárias depositadas no AHU, cronistas e a historiografia sobre o tema. Todo o debate se dá a luz do conceito de mestiçagem desenvolvido por Serge Gruzinski que observa o fenômeno como elemento que atingiu a civilização moderna à medida que integravam-se os povos e os espaços do Novo Mundo ao projeto ibérico de expansão. As variedades surgidas para as práticas do catolicismo foram múltiplas, diferenciando-se nas duas regiões estudadas, mas sem deixar de envolver lusos e autóctones de forma completa tornando-se vetores para a propagação de práticas mestiças em outras partes do globo.
\end{abstract}

Palavras-chave: mestiçagem, catolicismo, gentilismo.

\begin{abstract}
This work deals with cultural mixing processes that occurred in the Iberian enclave of West Africa and Central West, especially in the forms of mixed Catholicism that arose in these regions; It provides a discussion about the relations built between the Lusitanian and indigenous, as well as the ways they found to live religions; It also shows the role of illustrated governor D. Francisco Inocêncio Sousa Coutinho and his actions to inhibit the gentilism. Therefore, the primary sources deposited were used in the AHU, chroniclers and historiography on the subject. The entire debate gives birth to the concept of mestizaje developed by Serge Gruzinski observing the phenomenon as a factor that hit the modern civilization as integrated to the people and the New World areas to the Iberian expansion project. The varieties that have arisen to Catholicism practices were multiple, differing in both regions analyzed, but seeking to involve indigenous and Lusitanian completely, thus becoming vectors for the spread of crossbred practices in other parts of the globe.
\end{abstract}

Keywords: mestizaje, catholicism, gentilism.

Artigo recebido em 12 de dezembro de 2015 e aprovado em 27 de junho de 2016.

* Doutora em História (UFPE), docente da Graduação e Pós-Graduação do Curso de História da Universidade Federal Rural de Pernambuco/UFRPE e Pós-Graduação da UFPE. País de origem: Brasil. E-mail: sue.almeida@uol.com.br

Horizonte, Belo Horizonte, v. 14, n. 42, p. 606-626, abr./jun. 2016 - ISSN 2175-5841 


\section{Introdução}

Nesta introdução buscamos explicar como interpretamos e nos apropriamos da polêmica categoria da mestiçagem. As misturas de ordem cultural e biológica ocorreram de forma planejada ou aleatória ao longo da trajetória da humanidade, no entanto, tratamos de um tipo de mistura que denominamos mestiçagem, que ocorreu a partir da expansão ultramarina ibérica e que atingiu nuances variadas nos lugares conquistados. Nosso olhar para a sociedade, que se formou nas conquistas portuguesas, apoiou-se nas reflexões de Serge Gruzinski, pois segundo o historiador a mestiçagem deve ser observada através das lentes de um processo que ele denominou de mundialização provocada pela expansão das navegações ibéricas, entre meados dos séculos XV e XVI. Para Serge Gruzinski, a mestiçagem está diante de nossos olhos, ela é um processo contínuo de encontros e refazimentos de culturas. O processo de mistura estaria sempre permeado pelo signo da ambivalência e ambiguidade. Considera-a como um fenômeno moderno que produziu mundos mesclados, criando imprevisibilidades e complexidades que foram vividas por indígenas, africanos, europeus e orientais. O processo de mestiçagem só se ampliou, e se tornou mais complexo, chegando aos dias atuais, ao que ele chama de "linguagem planetária". Embora os sistemas de valores das culturas em contato criem uma ilusão de divisão, os homens e as mulheres que interagem nestes mundos mesclados pertencem a ambas (GRUZINSKI, 2001, p. 26-27). Os homens e as mulheres mestiços/as viveram e vivem o dilema da fratura em suas identidades e exprimem em suas ações a complexidade das situações que nascem do confronto dos mundos. Mas os elementos que aparentemente são antagônicos "apresentam-se como as duas faces de uma mesma moeda", assim indivisíveis, indissociáveis, conciliáveis e compatíveis (GRUZINSKI, 2001, p. 28).

Partimos do princípio de que nesse mundo colonial mesclado nada foi inconciliável e irreversível, concluímos que o processo de formação dessas sociedades foi gestado a partir de encontros estabelecidos entre diferentes agentes sociais, portadores de valores e recursos diferenciados. Assim, os cativos africanos, 
por exemplo, na América portuguesa, fizeram suas escolhas conforme seus valores e bagagem cultural, apesar de disporem de um número bem menor de recursos para a ação do que os europeus e, até mesmo, do que as populações autóctones (os indígenas) (GOUVÊA E FRAGOSO, 2010 P. 18). Não podemos esquecer que independente da cor da pele, da qualidade e da condição, estar em terra estranha fez diferença para quem viveu o processo (BLUTEAU, 1728, P. 448 E 449). Apesar de serem produtos de mundos distantes, quando confrontados ibéricos e habitantes de Luanda, por exemplo, não foram impedidos de encontros que englobaram múltiplas facetas. A mestiçagem tanto aproxima como opõem elementos, criando mundos ambíguos dos quais é produto. Não é excessivo dizer que as sociedades criadas pelos processos de mestiçagem são polimorfas, compostas de identidades múltiplas e de constantes metamorfoses. Uma areia movediça como as dunas do Saara. Nesse trabalho, refletiremos sobre a experiência europeia, ou seja, os cristãos católicos em terras da África Ocidental e Centro Ocidental e como leram e se apropriaram da bagagem cultural local. Como a mestiçagem é uma via de mão dupla, acompanhamos os "brancos católicos" quando passaram a viver elementos das religiões locais, incorporando-os às suas vidas e, posteriormente, levando-os para Portugal ou a outra qualquer possessão ultramarina. Por sua vez, tentamos vislumbrar como os naturais da terra fizeram a incorporação, integração e transformação dos símbolos católicos às religiões e visões de mundo africanas, sendo também eles vetores para outras partes do globo.

Utilizar a mestiçagem, entendida como processo de formação das sociedades desenvolvidas pelas conquistas ultramarinas, é adentrar a um espaço no qual a mescla como aporte metodológico deve levar o pesquisador a escolher um campo de análise, ou seja, a que campo da mestiçagem o investigador se propõe a inquirir, em outras palavras, se a proposta é adentrar ao biológico ou ao cultural. Ela é uma parte constitutiva da construção social do Mundo Moderno permitindo que todos os fenômenos produzidos pela sociedade possam ser analisados a partir do seu crivo. Neste sentido, é legitimo que quando se envereda por uma investigação escolhendo a mestiçagem como ferramenta para analisar o social, escolha-se em 
seu universo de possibilidades um campo de verticalização para a pesquisa. A mestiçagem é uma categoria que foi alvo de debates como: ocidentalização, globalização e crioulização, apontados como resultados dos sistemas que envolveram "dominados" e "dominadores" e que resultaram em resistências e acomodações, espaços de liberdades e controle dos poderes. A Globalização e a Mundialização são apontadas por Serge Gruzinski como fenômenos coetâneos, iniciados com a expansão ibérica, mas que continuam num processo de redefinições constantes e que tiveram como ponto central de debate a questão do triunfo econômico americano, uma forma mais branda de referir-se ao "século americano". (GRUZINSKI, 2001, p. 194). Nestor Canclini aponta o fato de que a globalização cultural nada mais é que a americanização da cultura (CANCLINI, 1997, passin).

A crioulização é uma categoria que provocou um debate também acalorado e eivado de muitas divergências. Diversas interpretações surgiram sobre o fenômeno, todavia se desenvolveram calcadas nas pesquisas produzidas sobre as sociedades escravistas do Caribe e do sul dos Estados Unidos, e só posteriormente deslocandose para a África. O debate entre os "afrocêntricos" e "crioulistas", voltado a compreender a formação das sociedades crioulas na América, não nos serve para entender os processos de mestiçagem acontecidos na África, mesmo por que os teóricos trabalham com a categoria da hibridização, que na concepção de Gruzinski seria um estágio anterior ao da mestiçagem. ${ }^{1}$ No entanto, o "afrocêntrico" John Thornton não se prende apenas às construções identitárias de africanos na América, mas introduz a ideia considerada inovadora ao debate, de que a crioulização iniciou-se na própria África e que muitos escravos já estavam habituados a hibridação cultural intra-africana, antes de chegarem a América. Para justificar seu pensamento, exemplifica a influência do catolicismo no reino do Congo a partir do século XV. As reflexões de Thornton nos favorecem, pois nos dá o

\footnotetext{
${ }^{1}$ Para Serge Gruzinski na América do século XVI, a hibridização torna-se mestiçagem devido a um alargamento gigantesco de horizontes. Para ele houve interesses dos dois lados do oceano, a conquista provocou curiosidades estéticas e intelectuais. As relações aprofundaram-se, embora o híbrido coloque-se no lugar do exótico, mas ainda é o duplo (GRUZINSKI, 2001, p.195). Também para o conceito de hibridismo em contextos coloniais ver: BAHBAH, Homi K. O local da cultura. Belo Horizonte: Editora UFMG, 1998.
}

Horizonte, Belo Horizonte, v. 14, n. 42, p. 606-626, abr./jun. 2016 - ISSN 2175-5841 
tempo, entre os séculos XV e XVIII, para as transformações dos encontros de culturas de hibridação em mestiçagem, o que seria um fenômeno cultural mais profundo (segundo Serge Gruzinski), que já haveria rompido com o exótico e o duplo (híbrido), tornando-se as culturas em contato, uma cultura nova (PARÉS, 2005, p. 91).

Tais imbricações complexas nos obrigam a ampliar o espectro da reflexão histórica sobre o processo de colonização moderna, pois corrobora com o fato de compreender que:

As sociedades escravocratas foram em suas estruturas formadas mestiças fazendo parte das misturas senhores e escravos. No entanto, a inclinação para uma suposta pureza ou autenticidade característica das ciências sociais em uma determinada época do ocidente tornaram difíceis as reflexões sobre a mestiçagem (MARTIN, 2010, p. 17).

Não devemos entender essas sociedades como espúrias ou empobrecidas, mas, pelo contrário, como espaços em que as dinâmicas recriaram e reinventaram ações inéditas, tendo-se constantemente necessidade de "nomear o novo". Um exemplo dessa dificuldade está na definição do lugar dos indivíduos nascidos na América, resultado de uma mestiçagem biológica e cultural, para os quais não havia uma prévia definição nos mundos de onde vieram seus ascendentes (PAIVA, 2012, P. 20).

As sociedades nascidas da globalização inaugurada no século XVI promoveram encontros e desencontros entre o Velho Mundo e o Novo Mundo. O que os unia enquanto seres humanos não era o problema, o desafio consistia nas diferenças que os distanciavam. O que os distinguia assustava e, ao mesmo tempo, os fascinava. Os contatos e intercâmbios foram construídos na ambivalência, muitas vezes violentos, marcados pelo desejo de dominação e pela ambição. "Mas, a brutalidade não impede os artefatos de circular, os corpos de se entrelaçar, as palavras de se misturar (MARTIN, 2010, P.19)”. A dominação consiste em impor o pensamento do dominador sem, portanto, excluir a redefinição do dominado. Esse 
processo foi e não deixará de ser uma relação. Os encontros provocados por migrações ou intercâmbios entre índio, europeus e escravos se constituíram em terreno para a construção de um "mundo novo", com paradigmas antigos e assimétricos. Todavia, há um tipo de reciprocidade num longo e lento processo histórico no qual todos são transformados.

Em um pano de fundo de incompreensão e de humildade, de cumplicidade e solidariedade, nos mal-entendidos e nos pouco entendidos cada um constrói as suas referências onde o outro necessariamente entra, e todas essas referências dos uns e dos outros delimitam juntas o universo mestiço que eles terão daqui por diante de compartilhar (MARTIN ,2010, p. 17).

Dessas misturas, emergiu a invenção de uma sociedade, na qual todos precisaram sobreviver por opção, por acaso ou por coesão. Construiu-se a sociedade, mas foi preciso dar-lhe sentido, que variou segundo os grupos que a imaginaram. Eles não puderam ser isolados, haja vista que os mesmos tornaram-se os motores de novas formas de ver e viver.

\section{A Igreja Missionária}

O Ius Patronatus (Direito de Padroado) foi uma prática do Direito Germânico, que passou aos soberanos portugueses no século XVI. Com a fusão das três ordens de cavalaria - Cristo, São Bento e São Tiago - os monarcas passaram a ter regalias temporais e espirituais, o que impunha entre outras coisas que ao edificar igrejas em suas possessões ultramarinas possuíssem com estas unidades também direito e deveres. O dever consistia em prover o que fosse necessário para o sustento do culto, que ia da manutenção do templo ao sustento do clero. Um dúplice direito consistia na indicação dos ministros das igrejas, que seriam confirmados por quem pudesse dar-lhes a jurisdição e no de perceber os dízimos das circunscrições eclesiásticas (freguesias) que tivessem uma igreja titular. (OLIVEIRA MARQUES, 1995, p. 168). A origem do padroado remonta à Idade 
Média e está ligada ao sistema feudal e às ordens militares (OLIVAL, 2001, p. 3942).

Papas do século XV concederam o padroado como privilégios aos reis de Portugal, bem como às terras conquistadas, impondo-lhe a obrigação de levar até elas a fé católica. Foi o Papa Calisto III, pela bula Inter Coetera (13/03/1456), que concedeu ao Vigário de Tomar “nullius dioecesis”, ou seja, jurisdição espiritual sobre as conquistas portuguesas. Esta jurisdição consistia em poder confirmar os eleitos para os benefícios eclesiásticos nas novas terras; determinar penas canônicas tais como interditos, excomunhões e deposições; visitar ou mandar visitar as referidas igrejas; enviar bispos para conferir crismas, ordenações, consagrações de altares etc., isso até que os bispados fossem criados. O padroado abrangia as igrejas do norte da África que estariam submetidas ao rei, grão-mestre da Ordem de Cristo a partir de 1514 (RÊGO-FIGUEIRÔA; OLIVAL, 2011, P. 124). 2 As Dioceses de São Tomé e Príncipe, de Santiago de Cabo Verde e de Guiné-Bissau foram criadas por Clemente VII em 1533. Estas foram o resultado do desdobramento da Arquidiocese de Funchal. Elas abrangiam além das ilhas o enclave entre a Guiné e a conquista de Angola. Assim, essas regiões da África estavam atreladas a essas dioceses e às suas respectivas circunscrições espirituais, respeitando os direitos e deveres outorgados pelo padroado português, bem como, contribuindo para o processo de evangelização e vivência cotidiana do catolicismo tridentino nas possessões da África. É desse território espiritual que agora iremos tratar, particularmente dos problemas enfrentados pelo catolicismo vivido nas conquistas, espaços nos quais as trocas culturais redefiniram o dia-a-dia e as formas organizacionais das instituições para lá transplantadas.

\footnotetext{
${ }^{2}$ A ordem de nosso senhor Jesus Cristo foi criada em 1319, da desagregação dos Templários. Sua sede era em Tomar e tinha jurisdição canônica por concessão pontifícia sobre as terras conquistadas até a criação dos bispados. Em 1514, o poder de Tomar passa para as mãos dos reis portugueses, constituindo-se o padroado régio.
}

Horizonte, Belo Horizonte, v. 14, n. 42, p. 606-626, abr./jun. 2016 - ISSN 2175-5841 


\title{
2 Mestiçagens nas Ilhas em Geba e no Rio de Janeiro
}

As condições do rebanho do Senhor nas conquistas portuguesas sempre acompanharam o ritmo local. Já se disse que as elites locais formadas nas Ilhas de São Tomé e Príncipe se constituíram de homens negros e pardos que enriqueceram na lavoura ou com o comércio de escravos, fosse à compra e venda de peças, fosse participando dos negócios dos fretes ou da armação de navios. Esse poder econômico nas mãos de uma população majoritariamente de cor lhes permitiu transformar dinheiro em poder. Alcançaram os negócios político-administrativos, o senado da câmara, tendo acesso também aos provimentos eclesiásticos. Essa população foi muitas vezes designada, eufemisticamente, de "brancos da terra" (RÊGO-FIGUEIRÔA; OLIVAL, 2011, P. 125). Assim, não é de estranhar que o depoimento do Ouvidor Caetano Bernardo Pimentel Castro de Mesquita, em 1773, a Martinho de Melo e Castro, Secretário da Marinha e Ultramar, procurasse demonstrar o zelo de um bom católico, protegendo a fé dos desmandos locais. Diz ele:

\begin{abstract}
Na sé dessa cidade se acham de presente, deão, chambre, e dois cônegos brancos. Se acham acerdiagos, mestre escola e três cônegos pretos. Mais pardos e pretos esperam ser providos nas cadeiras vagas. Já expus na presença de V. Exc. a total ignorância do oficio sacerdotal dos quais todos os clérigos pretos sofrem e, os que mais serviam a religião. E que para cativar o seu péssimo procedimento têm entranhável ódio aos brancos. Esse comportamento tem sido a causa dos repetidos levantes que tem destruído as religiões até ao presente. Devendo-se ter um particular cuidado pela grande falta de brancos, e a liberdade em que se acham os negros por ter emprego que se lhes tem confiado. Persuado-me que aumentando o partido dos negros na catedral com ausência de alguns brancos que nela existem, tomarão os pretos ali todas as jurisdições e governo espiritual. Têm dado para seu partido um vantajoso passo por que os moradores brancos cada dia são menos (AHU- São Tomé, Caixa 15, Doc. 10, 04.10.1773).
\end{abstract}

O Ouvidor em sua narrativa deixa evidente que o clero da localidade é de cor, ávido por ampliar poder e jurisdição, aspiração que acarretava lutas, levantes e intrigas. É claro que essa dinâmica de inserção foi classificada como violência e péssimo procedimento e fora emoldurada por rituais católicos mesclados das 
práticas das religiões locais3, haja vista apontar-se a ignorância do aparato doutrinário do clero de cor, como um elemento crucial para a corrupção das práticas do catolicismo tridentino. A documentação não permite negar a força da população negra local, pois chegaram a impedir a criação de uma irmandade de Nossa Senhora do Rosário de brancos como sua congênere lisboeta no século XVIII (F. AGOSTINHO DE STA. MARIA, 1707, p. 436). Assim percebe-se, através do depoimento, uma realidade mesclada para os rituais e as vivencias do catolicismo nas ilhas. Saliente-se que a estrutura do cristianismo romano em São Tomé e Príncipe não era das mais carentes, pois possuía um espaço geográfico plenamente ocupado pela coroa portuguesa, o mesmo não se dando em outras áreas continentais da África.

A situação das religiões na Guiné, numa povoação chamada Geba, apresenta-se ainda mais preocupante para as autoridades reinóis envolvidas com um projeto de “cristianização”. O Capitão Mor da fortaleza de São Brás, Paulo José Alves, escrevendo a partir de Guiné-Bissau para o Secretário de Estado e dos Negócios da Marinha e Ultramar Martinho de Melo e Castro, faz uma meticulosa descrição das vivências espirituais do "rebanho católico" naquelas conquistas. As preocupações do Capitão se revelam no seguinte depoimento:

Outras informações posso dar a V. Ex ${ }^{\mathrm{a}}$ pelo que vim a conhecer daqueles países e seus indevidos ritos e costumes, no decurso de 13 anos que servi a sua majestade no mesmo continente, são as seguintes: A povoação de Geba é distante de Bissau pelos rios de cima 60 léguas e situada ente o gentio em desamparo, sem fortaleza nem tabanca ou estacada de fortificação e, sendo a população de cristãos seguem muitos ritos de gentilismo pelo que os mesmos gentios os provocam a que os sigam, pois os mesmos gentios estão vendo que os cristãos tem pouca força para irem contra eles e fazem mil insultos todos os dias aos ditos cristãos. Eles governam mais a povoação que os mesmos cristãos e, por esta mesma causa, os ditos cristãos são bastante inobedientes aos comandantes da Praça de Bissau a quem são subordinados (AHU- Guiné - Caixa 10, Doc.6a $1770 / 1795)$.

\footnotetext{
${ }^{3}$ Saliente-se que o clero majoritário nas ilhas era nativo e de cor, portanto, educado em um mundo mestiço no qual intergiam elementos tanto do catolicismos como dos gentilismos. Gentilismo: termo ultilizado na correspondência administrativa para referir-se às práticas religiosas inerentes às culturas africanas.
}

Horizonte, Belo Horizonte, v. 14, n. 42, p. 606-626, abr./jun. 2016 - ISSN 2175-5841 
Não é de estranhar que cristãos, grupo minoritário vivendo em terra estranha e inóspita, sejam abduzidos pelos costumes e rituais locais. Assim, em terras africanas, numa povoação chamada Geba, seria muito difícil resistir e/ou não vivenciar as experiências religiosas das populações locais e ainda mais quando as dioceses eram carentes de tudo. Não havia igrejas, curas de almas e muito menos bispos em terras africanas por longos períodos. O depoimento do Capitão Mor nos leva a pensar que as experiências vividas marcaram cristãos, gentios e mesclaram os rituais de ambos os grupos. Esse processo não deixou, inclusive, de alçar velas e atravessar os mares para as mais variadas possessões portuguesas. Os indivíduos se transformaram nos recipientes que preservaram e levaram o novo, ou seja, a mescla para outras partes do globo. Os estudos realizados sobre a América portuguesa na diocese do Rio de Janeiro durante o episcopado do bispo jacobeu D. Frei António do Desterro (1747-1773), demostra o quão mesclados estavam os ritos e os comportamentos dos "cristãos" de todas as nuances de pele nas plagas fluminenses. O bispo colocou em andamento um conjunto de medidas com o objetivo de reformar as práticas católicas vividas em sua diocese e na jurisdição que lhe competia, com o intuito de garantir o reto mistério da fé e a preservação da ortodoxia. Suas medidas incidiram sobre clérigos e leigos procurando garantir a observância dos princípios tridentinos e a aplicação efetiva das Constituições aprovadas na Bahia em 1707. No entanto, seu episcopado demonstra as grandes dificuldades e entraves que enfrentou para tal (PEREIRA, 2014, p.270). O catolicismo vivido em colônia ou enclaves/conquistas teve que enfrentar as vicissitudes da vida, batalha cotidiana entre o bem e o mal entre o viver e o morrer, assim toda a proteção propiciada fossem de crenças locais ou de além mar foram bem-vindas. 


\section{As religiões em Luanda}

Seguindo em direção mais ao sul pela costa da África atlântica, especificamente à cidade de Luanda, capital de Angola na segunda metade do século XVIII, mais precisamente em 1773, vamos encontrar uma cidade que abrigava uma população civil de condição livre, composta majoritariamente de pessoas negras e pardas. Eram 285 negros/as, contra 251 de brancos/as. Se somarmos os 993 escravos à população negra de condição livre, teremos o número de 1278 indivíduos, o que nos permite concluir que nesse universo havia uma influência significativa das práticas religiosas locais (REGINALDO, 2005, p. 32 e 33). Isto se infere, pela exiguidade de brancos (251) e ainda por sabermos que, sendo uma população de conquista, muitas vezes arregimentada nos extratos mais baixos da sociedade portuguesa, pois nobres e fidalgos eram poucos e adstritos aos postos de comando, só uma minoria foi educada segundo os padrões da ortodoxia do catolicismo tridentino ibérico. Adicionando-se ao já dito a constatação pela historiografia de que a mestiçagem entre europeus e mulheres africanas livres ou escravas, nos Reinos de Angola e Benguela, propiciou a crioulização dos portugueses e de sua cultura, impondo as comunicações cotidianas o idioma local o quimbundo (HEYWOOD, 2008, p. 103 e 104), o que demonstra, no que tange a divulgação das ideias, o poder da cultura local.

Durante o governo de Dom Francisco Inocêncio de Souza Coutinho, conhecido como o que desejou e trabalhou por uma Angola ilustrada4; que foi comendador da Ordem de Cristo e fazia parte do Conselho de sua majestade, foram desenvolvidas ações no sentido de "civilizar" essa possessão em terras de África (SANTOS, 2005, p.5). Para afiançar a propagação e a exaltação da chamada santa fé católica, trabalhou com afinco para garantir a extirpação do que ele nomeou de vícios gentílicos. Suas ações aparentaram ser uma tentativa evidente de coibir

\footnotetext{
${ }^{4}$ Dom Francisco Inocêncio de Sousa Coutinho assumiu o governo de Angola com a responsabilidade de reformar as bases do modelo administrativo que predominou nos séculos anteriores. O projeto estava em consonância com as orientações pombalinas, que traziam em seu bojo a ideia de civilizar, tão cara ao racionalizmo iluminista do final do XVIII. Ver: MONTEIRO, 1984, p. 105-108.
}

Horizonte, Belo Horizonte, v. 14, n. 42, p. 606-626, abr./jun. 2016 - ISSN 2175-5841 
costumes locais que estavam fora dos padrões católicos e da época das luzes. (AHU - Angola - Cx. 53, doc. 01, 10. 01. 1769).

Para afirmar a pureza dos costumes, Dom Francisco Inocêncio proíbe a realização dos entambes, rituais mesclados que se davam por ocasião da morte em Luanda e em Benguela (AHU - Angola - Cx. 53, doc. 01, 10. 01. 1769). Os entambes seriam funerais complexos, elaborados de forma a coexistirem os rituais católicos e africanos (HEYWOOD, 2008, P.109). Para o governador da região, a realização desse encontro de costumes não seria nada agradável ou compreensivo, pois classificava os entambes como um indício de barbárie praticadas pelos negros e, nos quais o governador podia observar, para seu horror, a participação dos brancos cujo comparecimento a esses eventos ele atribuía a uma falta de razão e de discernimento (AHU - Angola - Cx. 53, doc. 01, 10. 01. 1769). O primeiro Bando5 proibindo a prática dos entambes data de 1765. Segundo o documento a proibição estava associada à Lei Pragmática de 1749 e de 1759, pois ambas proibiam os lutos excessivos praticados por súditos. Dom Francisco articula o ritual a costumes herdados dos escravos e que, segundo o governador:

Contraria a pureza de nossa religião [...] não é possível que haja maior loucura, como a de fechadas as janelas e portas, cobertas as pessoas, de muitas batas negras, sem outra forma que a do artífice do tear; circundada a cabeça com uma corda, chorarem em altos e desagradáveis gritos, por muitos dias e por muitos meses, renovados os choros em certas horas, recebendo as visitas na mesma bárbara confusão. Acompanham os corpos escandalosamente a sepultura, com muitas negras chorando e persistindo em confusas lágrimas [...] ou com torpes e repugnantes ações de lascívia [...] cujo venerado obséquio do seu chamado entambe produz muita desordem e é inimigo da pureza da religião (AHU - Angola - Cx. 53, doc. 01, 10. 01. 1769).

Desde o século XVII que viajantes buscaram retratar costumes, por muitos considerados exóticos, das mais variadas regiões da África, como sugere a figura número 1 (um), que busca esclarecer um pouco dos sucedidos em Luanda algumas décadas depois.

\footnotetext{
${ }^{5}$ Segundo Bluteau (1728), bando significa pregão, quando se declara publicamente um decreto ou lei ao som de caixa.
} 


\section{FIGURA 1- Ritual fúnebre na Senegâmbia, final do século XVII}

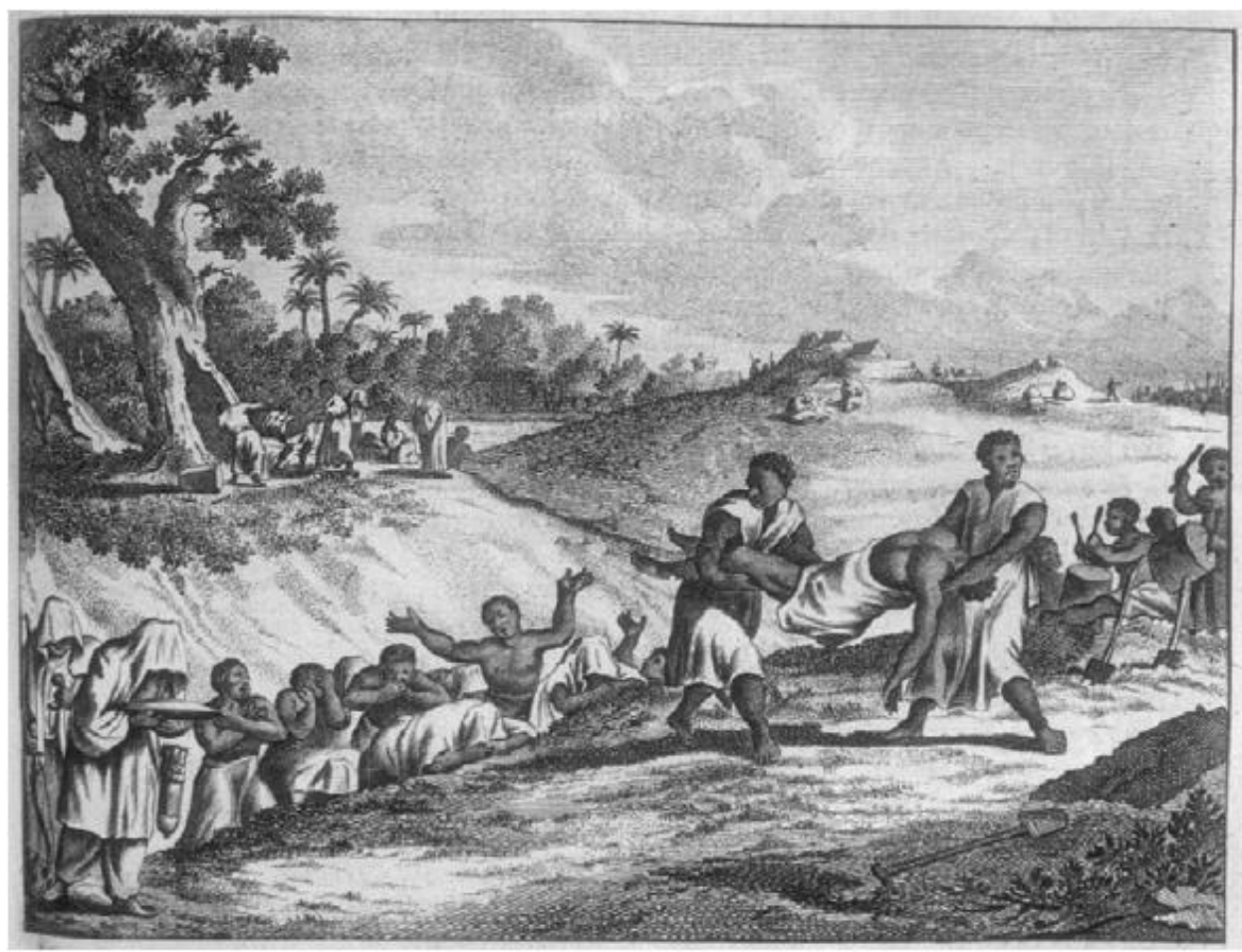

Fonte: Dapper, 1686, p. 235.

Elias Alexandre, militar baiano e radicado em Santa Catarina, que serviu em Luanda no século XVIII e autor de uma "História de Angola”, também descreve os entambes:

São insuportáveis por tristes e afetados. Os lamentos são cantados pelas ruas, exprimidos no idioma do país por boca dos escravos dos defuntos. Estes como máquinas ambulantes, avisam pelo triste canto a parentela dispersa na cidade, e se o morto é cidadão excede a música e dois coros. Os semblantes de natureza carrancudos, se afeiam ainda mais, com os soluções, que servem de estribilho no fim de cada cantoria, com tudo, as lágrimas não umedecem o exterior dos olhos, a tristeza é estudada. Os entambes são celebrados com um oitavário de abomináveis superstições, que finda santamente com uma missa aplicada pela alma do defunto. Este ato religioso, celebrado no templo, com modéstia e tristeza, é depois em casa seguido por um batuque extenso, que rompe e desgasta o enojo dos parentes. Os chinguilamentos, se misturam com os atos do cristianismo onde desaparece a fé misteriosa e revelada, para se unir a efeitos incertos, falsos, sobrenaturais. Os destinos fechados com o selo do silencio eterno, são anunciados por agouros ridículos, e pelos nojentos efeitos dos seus milongos (feitiços, remédios de ervanário). Os seus gangas aceitam essas misturas, os párocos são inclinadas as indulgências, e bispos que resistiram só conseguiram irritar os caprichosos (CORRÊA, 1937, P.8388). 
As religiões e os hábitos se misturaram evidenciando-se nos rituais através dos cultos das religiões locais, que por sua vez, se inseriram nos rituais católicos vividos no cotidiano das conquistas, como revelam os depoimentos acima citados. Essa experiência de Luanda pode ser inferida também para a América portuguesa, guardadas as especificidades locais. As infiltrações e mestiçagens foram fenômenos de mão dupla, pois da mesma forma que rituais africanos penetraram em espaços "católicos", o inverso também ocorreu, a exemplo de uma imagem de Nossa Senhora da Conceição, branca, ter sido encontrada entre os ídolos gentios Moçosos e Maungos. Esta retirada e encaminhada para restauro no Brasil no período do governo de Francisco Inocêncio de Souza Coutinho (AHU, Angola, cx.51, doc.19). Objetos sagrados do cristianismo católico foram usados em conjunto com Nkisifetiches como fonte de poder espiritual (REGINALDO, 2005, p.40).

Mas voltemos aos reclamos do Governador. Ele classifica a realização dos entambes como verdadeiro centro de desordem pública, de roubos e superstições escandalosas. Diz “que lhe parece que a experiência em abusos vividos pelos pais de família" seria o suficiente para proscrever das suas casas o tão desordenado costume (AHU - Angola - Cx. 53, doc. 01, 10. 01. 1769). No entanto, as proibições da realização de tais eventos não foram suficientes para arrefecer os ânimos dos frequentadores. Estes burlavam a lei, ato bem mais criminoso na visão do governador, pois saindo da capital iam realizar o tal entambe nos arrimos ${ }^{6}$, locais favorecidos pelas distâncias, e que garantiam proteção àqueles que transgrediam as leis inclusive para os escravos das fazendas. Eles persistiam e não arrefecia seu ânimo em praticá-los mesmo sujeitos a punições.

Em janeiro de 1769, Dom Francisco requereu que se impusessem penas dobradas aos frequentadores dos entambes, pois se tratavam de práticas contrárias às determinações do Bando de 1765, e o governador acreditava que a severidade das leis deveria ser exercida contra as casas aonde se realizavam tais eventos (AHU - Angola - Cx. 53, doc. 01, 10. 01. 1769). Para o governante de São Paulo de

\footnotetext{
${ }^{6}$ Arrimos eram propriedades agrícolas ao redor de Luanda.
} 
Assunção de Luanda, o Bando deveria ser publicado todos os meses pelos capitães mores e cabos, em todo o lugar público onde houvesse aglomerações. Este deveria ser traduzido na língua local com a finalidade de ninguém alegar desconhecer ou ignorar as determinações, inclusive, devendo ser divulgadas primeiramente nos auditórios da capital (AHU - Angola - Cx. 53, doc. 01, 10. 01. 1769).

Neste sentido, a redação do Bando insiste e determina que jamais se possa, em algum lugar daquele reino, admitir os ditos infernais rituais e que toda e qualquer pessoa que tiver notícia deve prontamente denunciá-los aos ministros, eclesiais e seculares, para procederem com a acusação na forma da lei. Aquele que fizesse o contrário, ocultando os entambes, deveria ser preso e processado como se tivesse ele mesmo cometido os atos de celebrações gentílicas. Os capitães mores deveriam ainda vigiar continuadamente o cumprimento dessas ordens, não permitindo os entambes e, ainda mais, que nas casas ou senzalas aonde o tal fosse praticado, todos os participantes deveriam ser levados presos para cumprir pena nas obras reais, conforme determinava os bandos de 1765 e 1769 (AHU - Angola Cx. 53, doc. 01, 10. 01. 1769).

Mas a cultura local se mestiçava continuamente e isso era notório para além dos rituais de morte, também se mesclavam os rituais de casamento. O Governador os descreve sendo iniciados por uma figura "coberta de pele de bicho e de guizos, sinalizando para outras cerimônias que não declara por decência," atribuindo essas práticas como dignas das "Libatas dos potentados dos sertões e de nenhum modo de uma capital de reino conquistado gloriosamente para o cristianismo" (AHUAngola - Cx. 49 - Doc. 4, 09.01.1765). Essa e outras cerimônias podem ser inferidas pelas narrativas do já citado Elias Alexandre, quando descreve os cerimoniais de casamento em Luanda, afirmando que estes se davam em algumas ocasiões entre brancos e negros, aproximando e mesclando os eventos culturais e os rituais. 
A leitura do Bando proclamado por Dom Francisco de Souza Coutinho revela a sua perplexidade diante de uma prática pagã antiga, supostamente suplantada pela evangelização. Ele constata que, ao contrário, teria havido uma mistura dos rituais religiosos cristãos ibéricos com elementos da cultura dos povos conquistados como o entambe exemplifica. Ele descreve as práticas dos povos da região em momentos extremos em que a fé deveria promover a preservação da vida. Segue sua narração de forma livre:

Souza Coutinho menciona que foi exposto à veneração pública, um ídolo com o nome de Bumba, que fez com que a população deixasse de cumprir os preceitos dos dias santos que deveriam ser consagrados a Deus. Os veneradores passaram a guardar o dia imediato à lua nova anatematizando, ou seja, amaldiçoando, com superstições, as negras que participavam das adorações e propondo que estas deveriam morrer e procurar ressuscitar, pois comprovariam o poder do Bumba. Talvez aqui seja possível antever uma disputa entre sacerdotes gentílicos e o clero católico local. Uma quebra de braço entre divindades para que através de milagres materializados nos corpos das negras, pudessem provar seu poder ressuscitando-as, e consequentemente conferindo aos sacerdotes e adoradores pagãos poder sobre a população. Todos esses atos considerados ilícitos pelo governador, essa efervescência em vivencias e práticas, seriam realizados nos mesmos dias sagrados em que a Igreja com todos os seus fiéis veneravam os mistérios da salvação (AHU - Angola - Cx. 53, doc. 01, 10. 01. 1769).

Esses argumentos são tecidos na documentação oficial para demonstrar que era crucial a interferência do monarca por meio de seus governadores laicos, embora estes nunca estivessem totalmente desvinculados das questões inerentes a fé católica, e teriam, inclusive, se utilizado da máquina administrativa para impôla. Mas também era essencial a ajuda dos eclesiásticos, pois com a exposição de poder da Igreja, fortalecer-se-ia a ideia de que todos deveriam dar conta de coibir, o que o governador considerava serem atos bárbaros e costumes diabólicos. Ele ordenou então, de imediato, que se destruíssem todos os locais, os objetos e todos 
os ídolos “fosse do Bumba ou de qualquer outra ilusão destes miseráveis”. Para ele deveriam ser remetidos para as obras reais, todos os que, sendo de dia ou de noite, realizassem o que ele entendia por invocações ao demônio ou fizessem sacrifícios aos mortos ou guardassem à lua nova. As ordens foram dadas aos capitães mores e cabos, cabia a estes fazê-las cumprir (AHU - Angola - Cx. 53, doc. 01, 10. 01. 1769). Como demostra a ilustração abaixo, as práticas para coibir os rituais gentílicos ocorreram em todos os enclaves de missionação católica. Queimar e demolir casas e palhoças, além de prender, condenar e executar adoradores foi um método recorrente imposto pelas autoridades reinóis no enclave angolano. Todavia as ações impositivas mostraram-se ineficientes, pois os corações e mentes, fossem africanas ou lusas, resistiram e carregaram durante a vida e para outros locais do Novo Mundo as crenças apreendidas.

FIGURA 2- Missionário capuchinho queima casa de ídolos na África CentroOcidental, década de 1740

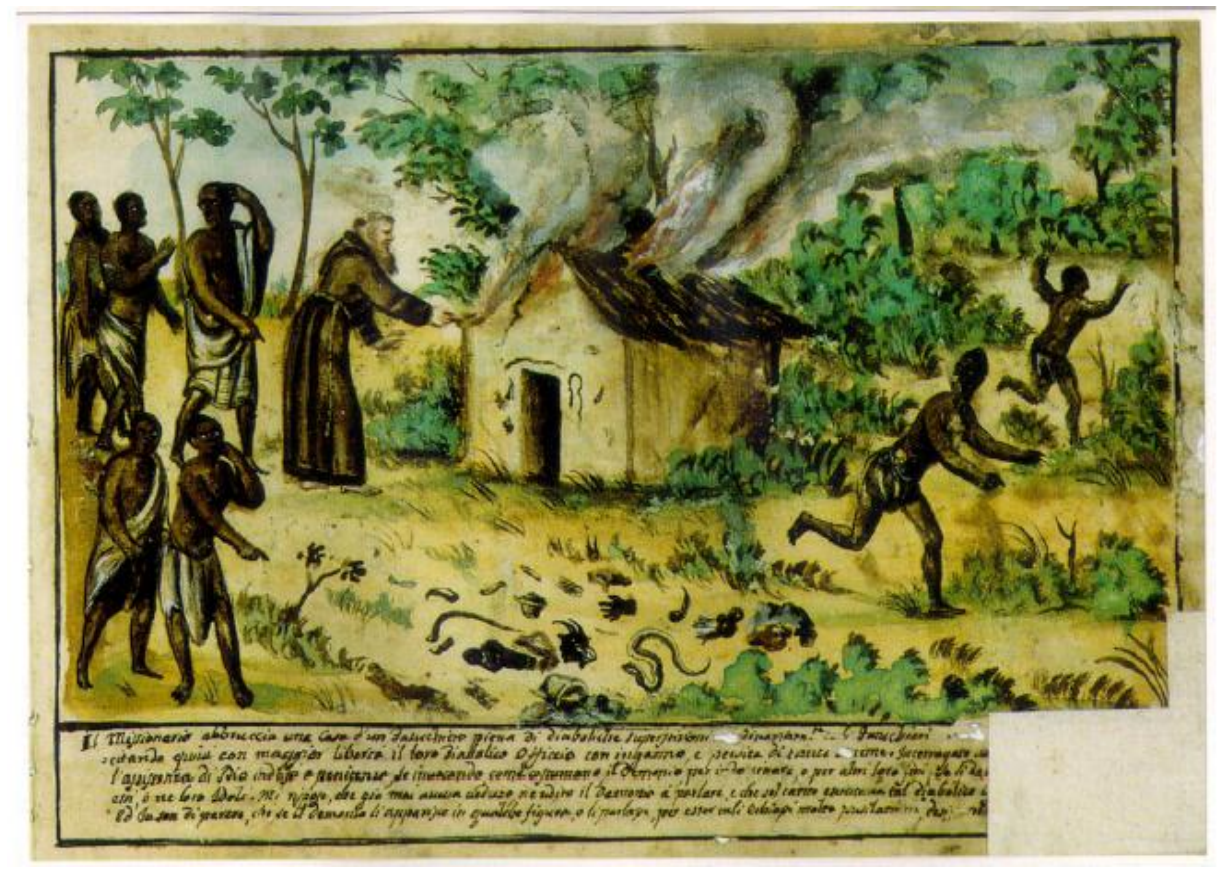

Fonte: Collo; Benso, 1986, p. 163. 


\section{Considerações Finais}

Todos os esforços, zelo e cuidados implementados pelas ações administrativas e de evangelização, fossem das ordens regulares ou do clero secular, se mostraram ineficazes em muitos aspectos, pois comprovaram obter pouco cumprimento e ressonância nos indivíduos de origem europeia e africana, tanto em Luanda quanto no interior. Se uma normativa não era aceita pela população, não transformava os hábitos. Afinal em 1780 se observava os brancos do interior praticando rituais ditos pagãos, participando de entambes, adivinhações e adoração a ídolos, além do que, a presença de práticas africanas junto ao centro dos rituais da Igreja ainda nos idos de 1790 foi desafiadora. Neste momento, o exercício de rituais afro-cristãos comandavam os sacramentos na região, tais como: funerais, casamentos e a própria comunhão (HEYWOOD, 2010, P.110).

Os rituais em torno dos enterros fossem dos africanos e seus descendentes ou não, estavam cercados de múltiplos significados. O desejo de encontrar os ancestrais e o medo de não merecerem um bom lugar no além-vida, levava ao cuidado para deixar bem claro o que se queria nas realizações das cerimônias finais. No entanto, como verificamos através das fontes citadas, o cotidiano se encarregava de misturar as crenças. Os lusos chegados aos enclaves portugueses na África ao longo do tempo foram misturando os ritos, doutrinas e teologia cristã às cosmologias das experiências religiosas locais. É claro que sabemos que alguns elementos ficaram intocados, da mesma forma que pessoas tanto lusas quanto africanas permaneceram em suas crenças e fé, mas muito se ressignificou, imbricou e circulou em um processo quase infinito, mesclando-se. E este redemoinho avassalador de renovação se comprova pela insistência da documentação administrativa portuguesa em apontar para uma rigorosa punição àqueles que insistissem nos rituais mestiços em Angola. Além da mestiçagem racial, a mestiçagem cultural. O fenômeno parecia amedrontador para o governo português sediado em Luanda, justamente em um momento que o racionalismo e a ideia de 
civilizar eram mais prementes para a corte portuguesa, portanto banir o gentilismo era fundamental. No entanto, a cultura surgida em Angola, em especial nos espaços onde havia uma imposição da máquina administrativa portuguesa, englobando neste contexto o aparato religioso era mestiça. Criou-se um conglomerado de elementos da cultura portuguesa católica misturados aos elementos da cultura local dos mais variados matizes e temas. Se por um lado, os encontros culturais impuseram um "jeito português de ser", como se vestir à europeia, ou até falar a língua portuguesa, a cultura colonial lusa ou de conquista, se encarregou da apropriação da cultura quimbundo, e vice-versa, transformando-se em algo que não estava previsto nem pela Coroa e nem pela Igreja.

Para James Sweet o Deus cristão e os santos católicos foram incorporados ao panteão das divindades centro-africanas. Os santos foram comparados aos espíritos ancestrais e utilizados para socorrer resolvendo problemas temporais específicos. Para o autor, os símbolos católicos foram transformados e integrados as religiões e visões do mundo africano. Assim conclui pela não destruição das crenças africanas, mas pela incorporação, reinterpretação e absolvição dos ritos cristãos enriquecendo as religiões locais (SWEET, 2003, p.103, 194 e 205). Já John Thornton viu o catolicismo construindo canais de comunicação com a tradição centro - africana (THORNTON, 2004, p. 261-278). Dessa forma, acreditamos que as expressões religiosas desse grupo mestiço foram marcadas por sínteses ritualísticas amalgamadas por leituras e cosmovisões da cristandade lusa passíveis de serem lidas e reinterpretadas pelas religiões locais e vice-versa (SOUSA, 1996, p. 34). A reflexão feita nos leva a intuir que surgiu em África de enclave português, uma variante do catolicismo ibérico, construída à luz de uma reinterpretação feita por ambos os lados, lusos e africanos e não só em Angola, mas que atravessou o Atlântico ou deslocou-se para o reino, promovendo ora de forma intensa, ora de forma sutil uma releitura dos ritos de fé. 


\section{REFERÊNCIAS}

AHU- São Tomé, Caixa 15, Doc. 10, 04.10.1773

AHU- Guiné - Caixa 10, Doc. 6-a 1770/1795. "Noticia apresentada pelo Capitão - Mor da fortaleza de S. Brás, Paulo José Alves, ao Ministro e Secretario de Estado dos Negócios da Marinha e Ultramar, Martinho de Melo e Castro sobre Bissau e outros lugares da Guiné”.

AHU- Angola - Caixa 49, Doc. 4, 09.01.1765. Bando de Francisco de Souza Coutinho, Governador de Angola.

AHU - Angola - Caixa 53, Doc. 01, 10. 01. 1769. Bando que proíbe os Entambes (a), e outras barbaridades.

BAHBHA, H. K. O local da cultura. Belo Horizonte: Editora UFMG, 1998.

BLUTEAU, R. Vocabulário Português e Latino [...]. Coimbra: Collégio das Artes da Companhia de Jesus, 1728.

CANCLINI, N. G. Consumidores y cuidadanos. Conflictos multiculturales de la globalización. Grijalbo: México, 1995.

CARVALHO, F. M. Sobas e homens do rei: relações de poder e escravidão em Angola (séculos XVII e XVIII). Maceió: EDUFAL, 2015.

COLlO, P.; BENSO, S. (Orgs.). Sogno: Bamba, Pemba, Ovando e altre contrade dei regni di Congo, Angola e adjacenti. Milan: Published Privately by Franco Maria Ricci, 1986.

CORREAA, E. A. S. História de Angola. Lisboa: Editorial Atica, 1937.

DAPPER, D. O. Description de l'Afrique [...]. Amsterdam: Traduite du Flamando, 1686.

FREI AGOSTINHO DE SANTA MARIA. Santuário Mariano [...]. Lisboa: Oficina de Antônio Pedrozo Galrão, Tomo V, 1707.

GOUVÊA, M. de F.; FRAGOSO, J. (Org.) Na Trama das Redes: política e negócios no império português, séculos XVI- XVIII. São Paulo: Civilização Brasileira, 2010.

GRUZINSKI, S. O Pensamento Mestiço. São Paulo: Companhia das Letras, 2001. HEYWOOD. L. M.(Org.). Diáspora negra no Brasil. São Paulo: Contexto, 2008.

MARTIN, DENIS-CONSTANT. A herança musical da escravidão. Revista Tempo, v.14, n.28, Jan-Jun de 2010. 
MONTEIRO, Nuno Gonçalo. O reformismo ilustrado luso-brasileiro: alguns aspectos. Revista Brasileira de História. São Paulo, n.7, p. 105-108, 1984.

OLIVAL, F. As ordens militares e o Estado Moderno: honra, mercê e venalidade em Portugal (1641-1789). Lisboa: Estar Editora, 2001.

OLIVEIRA MARQUES, A.H.R. História de Portugal. 3vols, Lisboa: Editorial Presença, 1997.

PEREIRA, A. M. S. A legislação sobre escravos no episcopado de D. Frei António do Desterro, Rio de Janeiro (1747-1773). In: OLIVEIRA, A. J. M. de; MARTINS W. de S. (Orgs.). Dimensões do Catolicismo no Império Português. Rio de Janeiro: Garamond, 2014. Cap. 9, p. 267-332

PAIVA, E. F. Dar nome ao novo: uma história lexical das Américas portuguesa e espanhola entre os séculos XVI e XVIII (as dinâmicas de mestiçagem e mundo do trabalho). Minas Gerais, 2012, 25of. Tese (Para concurso de professor titular em História)Departamento de Filosofia e Ciências Humanas, Universidade Federal de Minas Gerais.

PARÉS, L. N. O processo de crioulização no Recôncavo baiano (1750-180o). Afro-Ásia, n. 33, 2005, p. $87-132$

RÊGO-FIGUEIRÔA, J. de; OLIVAL, F. Cor da Pele, distinções e cargos: Portugal e espaços atlânticos portugueses (séculos XVI a XVIII). Revista Tempo. n. 30, 2011.

REGINALDO, L. Os rosários dos angolas: irmandades negras, experiências escravas e identidades africanas na Bahia setecentista. Campinas, 2005, $251 \mathrm{f}$. Tese (Doutorado em História) - Instituto de Filosofia e Ciências Humanas, Universidade Estadual de Campinas.

SANTOS, C. M. Um governo "polido" para Angola. Reconfigurar dispositivo de domínio (1750-c.1800). Lisboa, 2005. 637 f. Tese ( Doutorado em História) - Faculdade de Ciências Sociais e Humanas, Universidade Nova de Lisboa.

SOUSA, A. M. R. B. T. de. D. Francisco de Sousa Coutinho em Angola: reinterpretação de um governo 1764-1772. Lisboa, 1996, 170f.Dissertação (Mestrado em História)-Faculdade de Ciências Sociais e Humanas, Universidade de Lisboa.

SWEET, J. Recreating África. Culture, Kinship, and Religion in the África Portuguese World, 1441-1770. Chapel Hill and London, The University of North Carolina Press, 2003.

THORNTON, J. África and Africans in the making of the Atlantic Wold, 140o1800. Cambridge: C. University Press, 1998. 